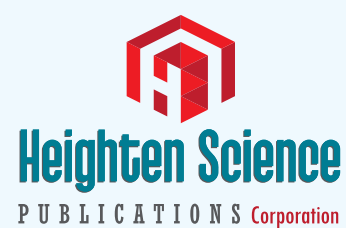

ISSN

2640-284X

\title{
Effect on Vitamin D status of Breastfeeding Infants after Vitamin D3 Supplementation during Breastfeeding Lactation: A double-blind randomized controlled trial
}

\author{
Sathit Niramitmahapanya ${ }^{1 *}$, Surasak Kaoiean ${ }^{2}$, Varaporn \\ Sangtawesin ${ }^{3}$, Anusorn Patpanaprapan ${ }^{1}$, Narisa K Bordeerat ${ }^{4}$ \\ and Chaicharn Deerochanawong ${ }^{1}$ \\ 'Endocrinology and Metabolism Unit, Department of Medicine, Rajavithi Hospital, College of \\ Medicine, Rangsit University, Bangkok, Thailand \\ ${ }^{2}$ Division of Maternal-Fetal Medicine, Department Obstetrics and Gynecology, Rajavithi \\ Hospital, College of Medicine, Rangsit University, Bangkok, Thailand \\ ${ }^{3}$ Assistant Professor of Neonatal Unit, Queen Sirikit National Institute of Child Health, College \\ of Medicine, Rangsit University, Bangkok, Thailand \\ ${ }^{4}$ Department of Medical Technology, Faculty of Allied Health Science, Thammasat University, \\ Phathumthani, Thailand
}

*Address for Correspondence: Dr. Sathit Niramitmahapanya, Endocrinology and Metabolism Unit, Department of Medicine, Rajavithi Hospital, College of Medicine, Rangsit University, Bangkok, Thailand, 10400, Tel: +662 3545105; Fax: +662-3548179; Email: maisathit@hotmail.com

Submitted: 20 July 2017

Approved: 02 August 2017

Published: 04 August 2017

Copyright: @ 2017 Niramitmahapanya S, et al This is an open access article distributed unde the Creative Commons Attribution License, which permits unrestricted use, distribution, and reproduction in any medium, provided the original work is properly cited

Keywords: Breastfed infant; Vitamin D supplementation; Lactation

Check for updates

\section{ABSTRACT}

Background: Vitamin D deficiency in pregnancy increases several risks of breastfed mothers. To prevent these adverse events, vitamin D supplementation during pregnancy and lactation is recommended, but suggested dose ranges vary.

Objective: To determine whether vitamin D3 1,800 IU/d supplementation in lactating mothers improves the vitamin $D$ status of their breastfed infants.

Materials and Methods: A randomized, placebo-controlled trial with Thai pregnant women was conducted. Lactating mothers $(n=72)$ and their breastfed infants with insufficient maternal 25 hydroxyvitamin $D(25(O H) D)$ levels in the third trimester were randomly assigned to two groups, one of which received 1,800 IU/d vitamin D supplementation and the other a placebo. Maternal serum 25(OH)D during lactation, cord blood, and 6-week breastfed infant serum were measured using LC-MS/MS

Results: Mean maternal age $( \pm S D)$ was $27 \pm 5$ years, and pre-gestational BMI was $22.29 \pm 5 \mathrm{~kg} / \mathrm{m} 2$. Maternal serum 25(OH)D at baseline was $22.29 \pm 7.15 \mathrm{nmol} / \mathrm{L}$. At 6 weeks, both maternal 25(OH)D and infant $25(\mathrm{OH})$ $D$ levels had increased significantly in the vitamin D supplement group of mothers and infants $(68.30 \pm 15.40$, $40.40 \pm 12.56 \mathrm{nmol} / \mathrm{L})$ compared to those in placebo groups $(55.15 \pm 13.57,24.28 \pm 17.20 \mathrm{nmol} / \mathrm{L})(p<0.001$, $\mathrm{p}<0.001)$. The changes in infant $25(\mathrm{OH}) \mathrm{D}$ levels increased substantially in the vitamin $\mathrm{D}$ supplement group but decreased in placebo $(17.49 \pm 16.27 \mathrm{ng} / \mathrm{ml}$ compared to $-1.34 \pm 19.23 \mathrm{nmol} / \mathrm{L}$ in the placebo group, $\mathrm{p}<0.001)$. The change of maternal $25(\mathrm{OH}) \mathrm{D}$ were positively correlation to the change of $25(\mathrm{OH}) \mathrm{D}$ level in breastmilk mothers and infants by $r=0.697, p<0.001$ and $r=0.379, p=0.003$ respectively.

Conclusions: Vitamin D3 supplementation to breastfed mother during lactation can increase serum 25(OH) D level in Thai breastfed mother and infants. Further work is needed to determine the optimum duration of vitamin D supplementation to normalized breastfed infants with $25(\mathrm{OH}) \mathrm{D}$ level $>75 \mathrm{nmol} / \mathrm{L}$.

\section{INTRODUCTION}

In children, long-term overt vitamin D deficiency leads to rickets with significant skeletal deformities and poor growth. Additionally, low vitamin D status at birth and in infancy has recently been linked to an increased risk of acute lower respiratory tract 
infections including respiratory syncytial virus infections [1-3]. The sources of vitamin $\mathrm{D}$ in breastfeeding infants are come from previous placental transfer, human milk and sunlight exposure. The vitamin D stores in the infant at birth depend on maternal vitamin D status during pregnancy and start physiologically with transplacental transfer of vitamin D as 25(OH)D [4]. It is well-known that there is a positive correlation between maternal and cord blood 25(OH)D concentrations, and, generally, the cord blood 25(OH)D level is between $50 \%$ and $80 \%$ of the maternal value [4]. Despite an abundance of sunshine, studies from the Middle East show that there is a high prevalence of vitamin D deficiency in women of childbearing age, mainly attributed to cultural avoidance of sunlight, traditional dress styles that cover most of the body while outdoors, and inadequate vitamin D intake [5,6]. Because the vitamin D status of the mother during pregnancy is important in determining the vitamin D status of the infant at birth, the strong relationship between maternal and cord blood vitamin $\mathrm{D}$ status [4] and vitamin D deficiency during pregnancy should be of concern, especially if the mother is planning to exclusively breastfeed.

In 2003, the American Academy of Pediatrics (AAP) published a guideline recommending that all children older than two months receive $200 \mathrm{IU}$ of supplemental vitamin D daily [7]. Subsequently, in 2008, the AAP issued an updated recommendation that all infants, children and adolescents receive a minimum of $400 \mathrm{IU}$ of vitamin D daily through diet or supplements [8]. Infants who are breastfed should receive $400 \mathrm{IU}$ of supplemental vitamin D daily [9-13]. Risk factors for vitamin D deficiency in infants were being exclusively breastfed without vitamin D supplementation; insufficient sunlight exposure; and low maternal vitamin D during pregnancy.

Vitamin D drops which are preferable for infants are not available in Thailand, and for this reason, vitamin D deficiency or insufficiency may occur during pregnancy and may increase the risk of abnormal fetal growth and bone development. It is still not clear whether supplemental vitamin D during the lactation phase of exclusive breastfeeding can improve the vitamin D status of infants. Our study aimed to determine whether vitamin $\mathrm{D}_{3} 1,800 \mathrm{IU} / \mathrm{d}$ supplementation in lactating mothers improves the vitamin $\mathrm{D}$ status of their breastfed infants. The primary objective of this study was to compare $25(\mathrm{OH}) \mathrm{D}$ levels of breastfed infants assigned vitamin D (VD) at 6 weeks postpartum with those given a placebo. The secondary aim was to compare levels of $25(\mathrm{OH}) \mathrm{D}$ of maternal serum and breast milk in the vitamin D and placebo groups at 6 weeks postpartum.

\section{MATERIALS AND METHODS}

\section{Material}

Two hundred pregnancies at the third trimester were enrolled in this study at Rajavithi Hospital, Bangkok. The parent protocol was approved by Ethics Committee of Rajavithi Hospital and the Ethics Committee of Queen Sirikit National Institute of Child Health, Bangkok, Thailand. All of the mothers delivered singleton infant at term ( $>37$ weeks) and planned to breastfeed their infants for over 2 months postpartum. Mothers who had 25(OH)D level $<25 \mathrm{nmol} / \mathrm{L}$ and $>75 \mathrm{nmol} / \mathrm{L}$ were excluded from this study. Healthy mothers were recruited from those who delivered at Rajavithi Hospital in Bangkok, Thailand between October 2013 and September 2014.

The vitamin D3 supplement pills used in this study were designed by the single commercial company in Bangkok and made from dried product of vitamin D3 of approximately $1,800 \mathrm{IU} /$ capsule.

A nurse at the antepartum unit was assigned to register more than 300 mothers into this study as shown in figure 1. After consent had been obtained, mothers' serum levels of 25(OH)D at the third trimester were checked and those who had 25(OH)D 


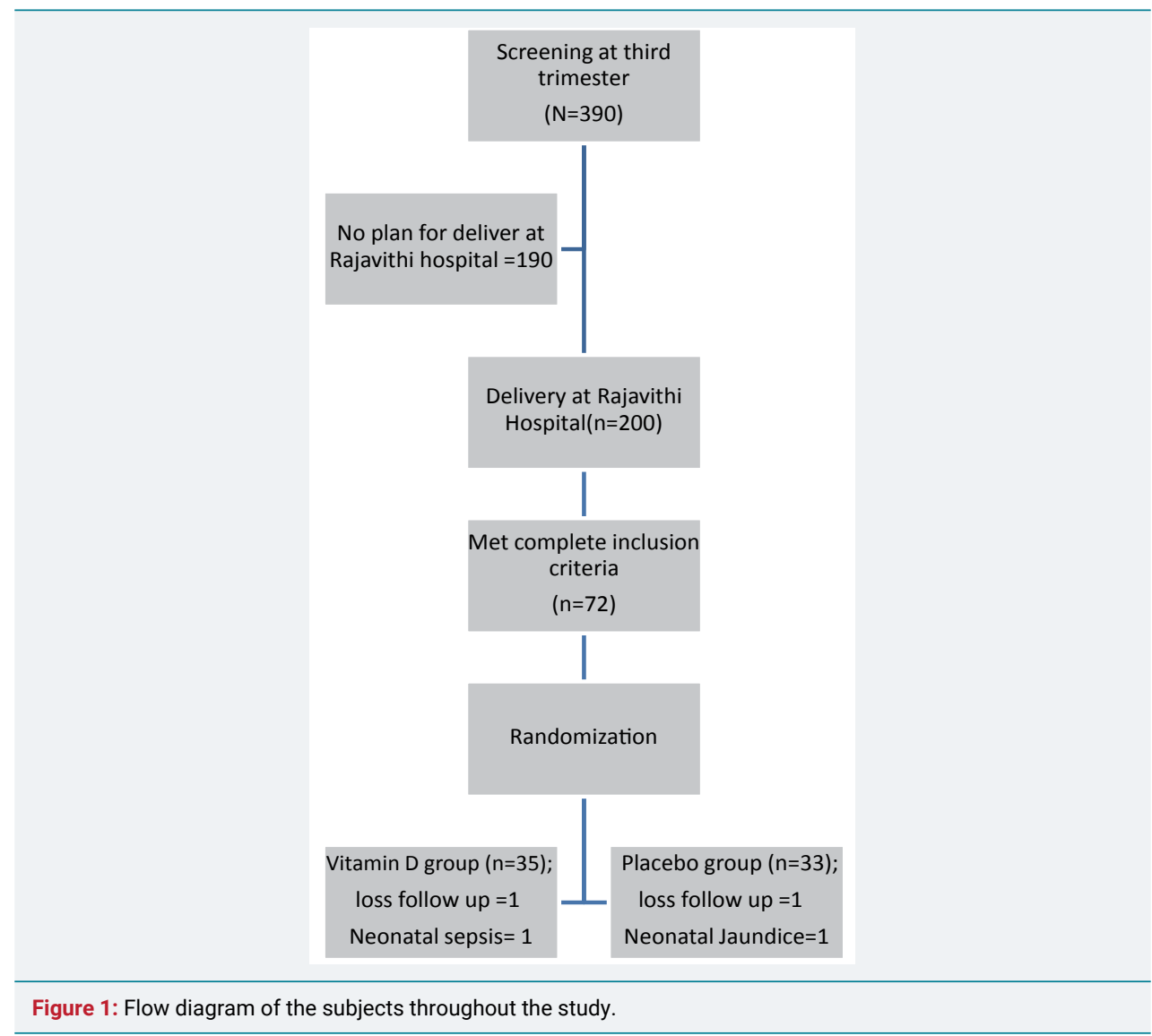

levels between 25 to $75 \mathrm{nmol} / \mathrm{L}$ were included in the study. 72 term infants of mothers with insufficiency vitamin D status were enrolled by research assistant officer into this study after delivery at Rajavithi Hospital if breastfeeding was planned for more than 2 months. Registered officers randomly assigned vitamin D3 and placebo capsules to breastfed mothers, and the obstetric physician was blinded to the participants' study arms. Cord blood, serum, urine and breast milk after delivery were collected from 102 mothers. At six weeks postpartum, 68 mother-infant pairs visited the postpartum clinic to complete demographic data and follow-up questionnaires, and mothers' blood, infants' blood ( $5 \mathrm{~mL}$ ), breast milk and mothers' urine were collected. 8 mothers were excluded from the study because of inadequate breast milk volume, and 26 motherinfant pairs were lost to follow-up at the 6-week appointment figure 1 . In case of 4 withdrawal participants, the reasons by 2 mothers were loss follow up, an infant was neonatal sepsis and another infant was neonatal jaundice.

\section{Method}

Blood samples were drawn by venipuncture from mothers and infants, and the mothers' urine and breast milk were collected and placed in the same container labeled with the date and the participants' names. The samples were frozen at $-80^{\circ} \mathrm{c}$ and send to Department of Medical Technology, Faculty of Allied Health Science, Thammasat University. Serum concentration of $25(\mathrm{OH}) \mathrm{D}$ of both mothers and infants were measured by the LC-MS/MS technique, Breast milk 25(OH)D levels were measured by the HPLC method, and vitamin D binding protein (VDBP) levels were measured by the solid phase sandwich ELISA method (R\&D Systems, Minneapolis, MN). For this assay, the manufacturer's reported intra-assay and inter-assay CV's are 6.2 and $7.4 \%$. The assay measured between $89-102 \%$ of exogenous VDBP added to human serum and has no significant cross-reactivity with human albumin, vitamin D3, or alfafetoprotein. Blood samples were available to measure serum intact parathyroid hormone (iPTH) using the chemiluminescence microparticle immunoassay (Abbott Diagnostics, U.S.A.) 
in Rajavithi Hospital for the same sample of mothers and infants. For iPTH assay, the detection limit was $4 \mathrm{pg} / \mathrm{mL}$ and has $0.01 \%$ cross-reactivity with $100,000 \mathrm{pg} / \mathrm{mL}$.

Follow-up questionnaires collected prospectively for the purpose of this study during the interview included socio-demographics, maternal skin color, maternal vitamin D supplementation and sunlight exposure behavior in mothers. During the study, mothers were contacted weekly by telephone by nurses who were experts in breastfeeding to ensure that infants were being breastfed and to resolve any breastfeeding problems until the 6-week postpartum visit. Sun exposure behavior was assessed by duration of sun exposure (hours/day) in the week prior to the interview. Both physicians and enrolled officers were blinded to the study arms of all participants.

\section{STATISTICAL ANALYSIS}

The variables of the study were maternal 25(OH)D breast milk levels, maternal 25(OH)D levels, and infants' 25(OH)D levels at delivery and 6 weeks postpartum. ANOVA was use to compare mothers and infants by group at the baseline and 6 weeks postpartum stages. We also compared selected maternal socio-demographic factors, dose of other source of vitamin D supplementation, sun exposure behavior, and mothers' skin color of the two groups using nonparametric statistical tests. Correlation analysis was performed to assess for the relationships among the changes in maternal vitamin D status, in breast milk vitamin D and in breastfed infant vitamin D status. Significant $p$ value less than 0.05 was set as statistical significant. Analysis was done with the software program SPSS for Windows version 17.0(SPSS Inc., Chicago, Illinois, USA).

\section{RESULTS}

The two study groups were same as preliminary results [14] include gestational age, proportion of male infant and urine calcium (Supplement Data). Gestational ages ranged from 37-41 weeks at enrollment. Mean $( \pm \mathrm{SD})$ baseline serum $25(\mathrm{OH}) \mathrm{D}$ values were $56.1 \pm 13.9 \mathrm{nmol} / \mathrm{L}$ in mothers (range $25.4-87 \mathrm{nmol} / \mathrm{L}$ ) and $24.8 \pm 12.1 \mathrm{nmol} / \mathrm{L}$ in infants (range 6.8-64.5 nmol/L) as previous report [14]. Maternal 25(OH)D level at delivery, cord blood 25(OH)D level, Colostrum 25(OH)D level and proportion of normal labor not showed any significant difference in both groups. Postpartum maternal $25(\mathrm{OH}) \mathrm{D}$ concentrations in the mothers and their infants at 6 weeks postpartum were positively correlated $(\mathrm{r}=0.44 ; \mathrm{p}=0.001)$.

\section{Maternal outcome}

Baseline maternal age, 25(OH)D concentrations, vitamin D binding protein levels and gestational age were greater in the placebo group. Maternal serum 25(OH)D values increased in the vitamin D groups from baseline to day 42 (6 weeks)(Table 1), and this incremental change in maternal serum $25(\mathrm{OH}) \mathrm{D}$ was significantly greater in the vitamin D group than in the controls. Breast milk cholecalciferol concentrations mirrored serum concentrations, with increased serum values at 6 weeks postpartum in the vitamin $\mathrm{D}$ group only $(\mathrm{p}=0.005)$ (Table 1$)$.

\section{Infant outcome}

At birth, the cord blood concentrations of 25(OH)D were similar in the two groups. Birth weight, head circumference, length, Apgar score at 1 and 5 minutes, and the number of males were very similar (Supplement data). At 6 weeks postpartum, serum infant 25(OH)D levels and the change of infant serum 25(OH)D had significantly increased in the vitamin D group as shown in table 1 while other infant data such as head circumference, body weight, body length and serum calcium were not significantly different(data not shown) in the two groups (Table 1). The change of infant serum $25(\mathrm{OH}) \mathrm{D}$ levels was significantly higher in the vitamin $\mathrm{D}$ group $(\mathrm{p}<0.001)$. The change 


\begin{tabular}{|c|c|c|c|}
\hline Factors & $\begin{array}{l}\text { Vit. D group } \\
n=35\end{array}$ & $\begin{array}{c}\text { Control group } \\
n=33\end{array}$ & $p$-value \\
\hline Maternal $25(\mathrm{OH}) \mathrm{D}$ level at 6 weeks postpartum (nmol/L) & $68.30 \pm 15.40$ & $55.15 \pm 13.57$ & $<0.001^{*}$ \\
\hline Change of maternal $25(\mathrm{OH}) \mathrm{D}$ level $(\mathrm{nmol} / \mathrm{L})$ & $14.21 \pm 15.88$ & $-2.83 \pm 13.33$ & $<0.001^{*}$ \\
\hline Infant $25(\mathrm{OH}) \mathrm{D}$ level at 6 weeks postpartum $(\mathrm{nmol} / \mathrm{L})$ & $40.40 \pm 12.56$ & $24.28 \pm 17.20$ & $<0.001^{*}$ \\
\hline Change in infant vitamin $\mathrm{D}$ level (nmol/L) & $17.49 \pm 16.27$ & $-1.34 \pm 19.23$ & $<0.001^{*}$ \\
\hline Breast milk 25(OH)D level at 6 weeks postpartum (nmol/L) $\dagger$ & $97.49 \pm 19.32$ & $88.92 \pm 22.42$ & 0.10 \\
\hline Change of $25(\mathrm{OH}) \mathrm{D}$ level in breast milk (nmol/L) & $16.01 \pm 16.64$ & $3.05 \pm 19.55$ & $0.005^{*}$ \\
\hline Maternal urine calcium 6 wks (mEq/L) & $7.17 \pm 5.21$ & $7.84 \pm 8.37$ & 0.70 \\
\hline Maternal urine calcium/Urine creatinine $6 \mathrm{wks}$ & $0.07 \pm 0.04$ & $0.07 \pm 0.05$ & 0.82 \\
\hline
\end{tabular}

infant 25(OH)D level in supplement group is positive trend to increase level infant $25(\mathrm{OH}) \mathrm{D}$ different in placebo group is negative trend to decrease infant $25(\mathrm{OH}) \mathrm{D}$ level as shown in figure 2 .

In correlation analysis, the incremental change of infant 25(OH)D (nmol/L) level was found to be significantly correlated to the change in maternal 25(OH)D levels ( $\mathrm{r}=0.379, \mathrm{p}=0.003)$.Additional findings of the study were that the changes in breast milk $25(\mathrm{OH}) \mathrm{D}$ levels were correlated to maternal $25(\mathrm{OH}) \mathrm{D}$ changes $(\mathrm{r}=0.679, \mathrm{p}<0.001)$ but the changes in breast milk 25(OH)D levels did not show any significant correlation to the change in infant $25(\mathrm{OH})$ D levels $(\mathrm{r}=0.258, \mathrm{p}=0.055)$ as shown in figure 3 .

\section{DISCUSSION}

The purpose of the present study was to evaluate the possibility of vitamin D supplementation of breastfed infants through their mothers. Our study suggests that the milk of the vitamin D-supplemented mother may prevent infant osteomalacia (rickets) only if the dose given to the mother is large enough (1800IU/day). Prenatal and postnatal supplementation is advised for all infants by the Endocrine Society Clinical Practice Guidelines [15]. Previous studies have shown that high proportions of Malay and Thai pregnant woman are at risk of vitamin D deficiency[16,17], despite living in a country with plenty of sunshine, the majority of women in South East Asian countries had inadequate vitamin D levels of 25(OH)D $(<75 \mathrm{nmol} / \mathrm{L})$. A recent study [17] demonstrated that the prevalence of vitamin D inadequacy was $83.8 \%, 30.9 \%$ and $27.4 \%$ for first, second and third trimesters respectively. Vitamin D inadequacy is common in pregnant Thai women, and while vitamin D supplementation at $400 \mathrm{IU} /$ day is likely to prevent vitamin D deficiency in mothers, it is unable to prevent vitamin D insufficiency status in mothers even at $800 \mathrm{IU} /$ day. Our results showed maternal vitamin $D$ insufficiency status in the placebo group was $56.1 \mathrm{nmol} / \mathrm{L}$ at delivery period and $55.2 \mathrm{nmol} / \mathrm{L}$ at the 6 -week postpartum period.

In a previous report, when mothers received $200 \mathrm{IU}$ of vitamin $\mathrm{D}$ a day, the $25(\mathrm{OH})$ D concentration of breastfed infants was almost equal to that of infants receiving 400 IU/day directly [18]. The maternal 25(OH)D levels during the course of pregnancy showed a significant increase from the second to the third trimester [16,17]. As reported previously, 25(OH)D levels are relatively unaffected by pregnancy despite the increase in calcitriol levels and the passage of $25(\mathrm{OH}) \mathrm{D}$ across the placenta to the fetus [19].

Another study has suggested that human milk alone may provide sufficient dietary vitamin $\mathrm{D}$ for the needs of term infants under optimal social and environmental circumstances [20]. The dose of 900 IU of vitamin D daily [21] is not high enough to adequately boost breastfed infants' $25(\mathrm{OH}) \mathrm{D}$ levels, and even 1,000 IU/day is not sufficient [18], on the other hand, a double-blind study in South African showed a 


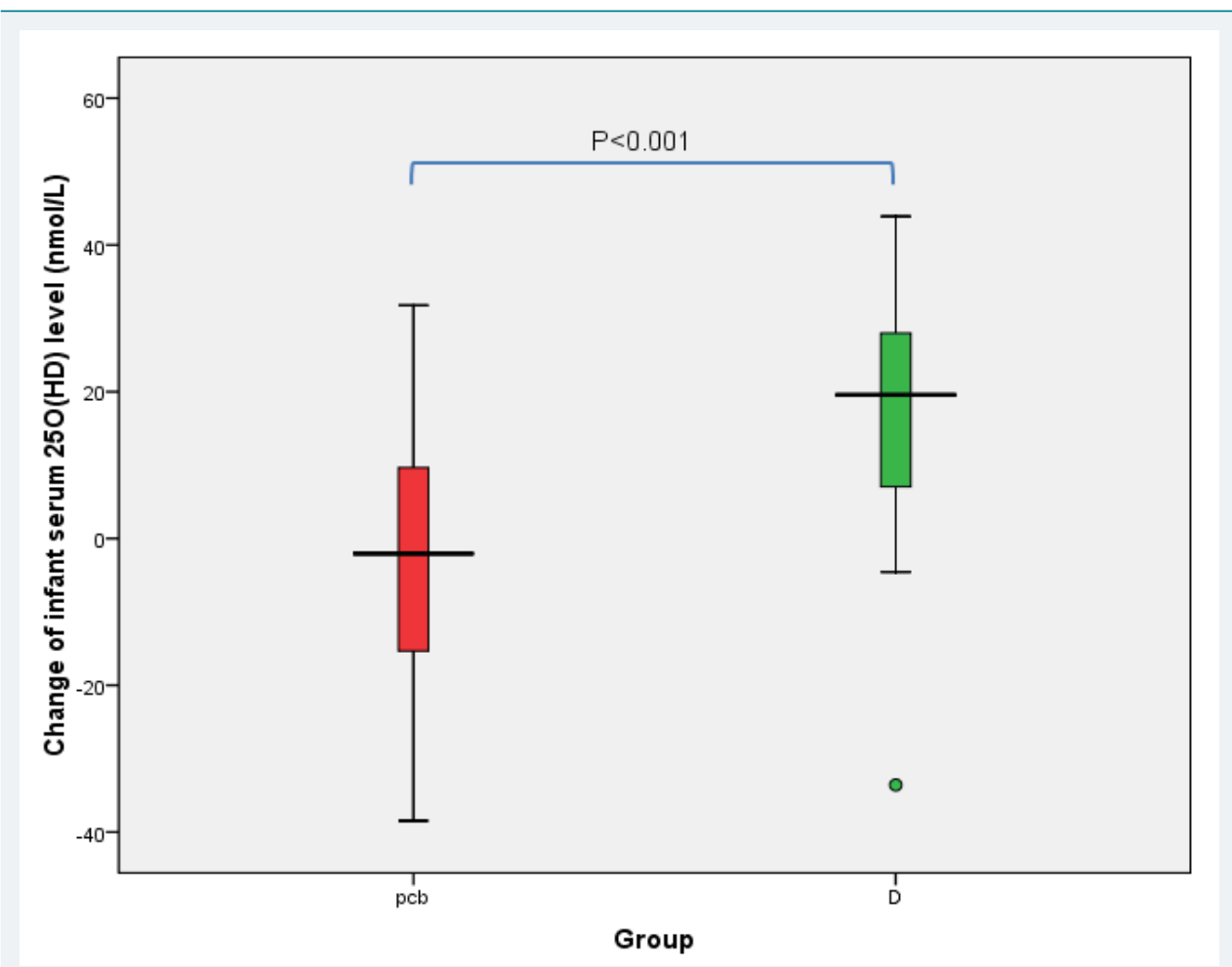

Figure 2: The change of infant $250 \mathrm{HD}$ level between the study groups; $p c b=$ placebo, $D=v i t a m i n ~ D$ group.

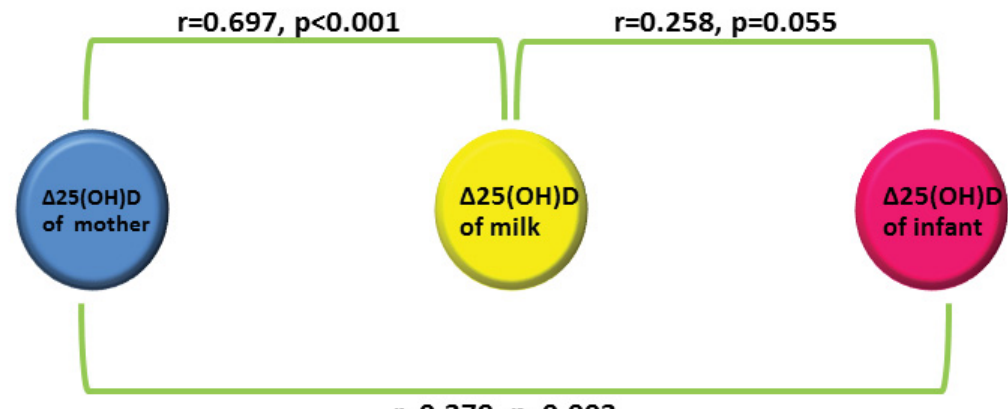

$r=0.379, p=0.003$
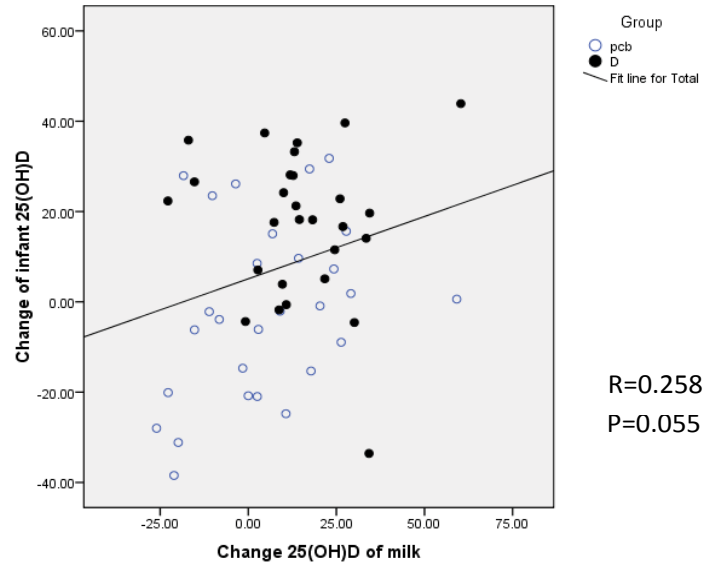

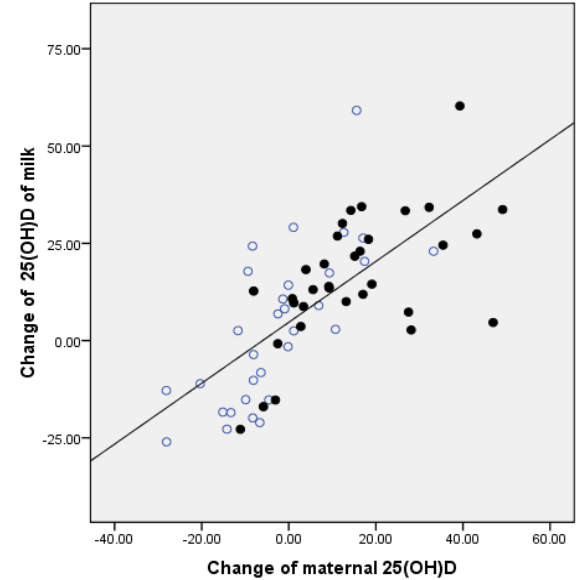

$\overbrace{0}^{\text {pcb }}$

Fit ine for Total

$\mathrm{R}=0.697$

$\mathrm{P}<0.001$

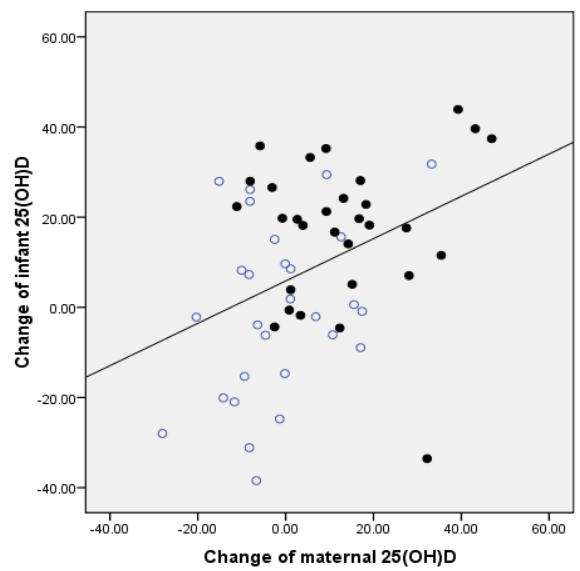

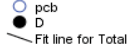

$\mathrm{R}=0.379$

$\mathrm{P}=0.003$

Figure 3: Correlation of change of maternal 25(OH)D, milk 25(OH)D and infant 25(OH)D (nmol/L) level. 
clear improvement in infant 25(OH)D concentration with 500 IU of daily vitamin D supplementation through the mother [22]. Our results suggest that $1,800 \mathrm{IU}$ of daily vitamin D3 supplementation in the mother can prevent vitamin D deficiency status in breastfed infants.

During an eight-week lactation period in another study, maternal $1 \alpha, 25(\mathrm{OH}) \mathrm{D}$ decreased to normal adult concentrations and remained quite constant thereafter[23]. In our study, six-week lactation showed a significant increase in breast milk 25(OH) D levels in the vitamin D-supplemented group, although this may have been due to the lower levels of colostrum 25(OH)D level in the vitamin D group compared to the placebo one. One infant in the vitamin D supplement group figure 2 did not show an incremental change of 25(OH)D levels, and this be a result of individual genetic variation, baseline of 25(OH)D level, an error in the measure and/or a lack of adherence to treatment.

There were some limitations of this study. First, the number of participants was quite small and there were several complicated stages in the collection and storage of specimens so that we were unable to show any correlation between the change of breast milk 25(OH)D levels and the change of infant 25(OH)D levels . Second, the method used to detect 25(OH)D level in breast milk was the HPLC technique which may interfere with proteins in breast milk. This study, however, was well designed to test the hypothesis and to study correlations among maternal breast milk and infant 25(OH)D levels between the vitamin D-supplemented group and the placebo one.

\section{CONCLUSION}

The vitamin D in breast milk is not sufficient to represent a secure way of vitamin D sufficiency status in Thai infants. A supplementation of vitamin D3 to the breastfed infant is not achieved to 25(OH)D to sufficiency status which we need more detail in further study. As this dose of vitamin D3 supplementation is quite high for lactating mothers, it has not previously been recommended for Thai lactating mothers.

\section{ACKNOWLEDGEMENTS}

We would like to thank the hospital project staffs and the pregnant women who participated in the research for their cooperation and support throughout the study. We wish also to express our gratitude to the National Research Council of Thailand for the research fund it provided.

\section{REFERENCES}

1. Wayse V, Yousafzai A, Mogale K, Filteau S. Association of subclinical vitamin D deficiency with severe acute lower respiratory infection in Indian children under 5 y. Eur $\mathrm{J}$ Clin Nutr. 2004; 58: 563567. Ref.: https://goo.gl/Z2SXwm

2. Roth $D E$, Shah $R, B$ Black RE, Baqui $A H$. Vitamin $D$ status and acute lower respiratory infection in early childhood in Sylhet, Bangladesh. Acta Paediatr. 2010; 99: 389-393.Ref.: https://goo.gl/1iKH8d

3. Belderbos ME, Houben ML, Wilbrink B, Lentjes E, Bloemen EM, et al. Cord blood vitamin d deficiency is associated with respiratory syncytial virus bronchiolitis. Pediatrics. 2011; 127: e1513-e1520. Ref.: https://goo.gl/MSPfza

4. Hollis $\mathrm{BW}$, Wagner $\mathrm{CL}$. Assessment of dietary vitamin $\mathrm{D}$ requirements during pregnancy and lactation. Am J Clin Nutr. 2004; 79: 717-726.Ref.: https://goo.gl/jGRCDZ

5. Dawodu A, Absood G, Patel M, Agarwal M, Ezimokhai M, et al. Biosocial factors affecting vitamin D status of women of childbearing age in the United Arab Emirates. J Biosoc Sci. 1998; 30: 431-437. Ref.: https://goo.gl/6K5osP

6. Gannagé-Yared MH, Chemali R, Yaacoub N, Halaby G. Hypovitaminosis D in a sunny country: relation to lifestyle and bone markers. J Bone Miner Res. 2000; 15: 1856-1862.Ref.: https://goo.gl/TuJeEu 
7. Seth A, Marwaha RK, Singla B, Aneja S, Mehrotra P, et al. Vitamin D nutritional status of exclusively breast fed infants and their mothers. J PediatrEndocrinolMetab. 2009; 22(3): 241-246. Ref.: https://goo.gl/Bh6R9s

8. Dawodu A, Tsang RC. Maternal vitamin D status: effect on milk vitamin D content and vitamin D status of breastfeeding infants. AdvNutr. 2012; 3: 353-361. Ref.: https://goo.gl/4pRizF

9. Yetley EA. Assessing the vitamin D status of the US population. Am J Clin Nutr. 2008; 88: 558-564 Ref.: https://goo.gl/QedwDQ

10. Taylor JA, Geyer LJ, Feldman KW. Use of supplemental vitamin D among infants breastfed for prolonged periods. Pediatrics. 2010; 125: 105-111. Ref.: https://goo.gl/jsRL6K

11. Perrine CG, Sharma AJ, Jefferds ME, Serdula MK, Scanlon KS. Adherence to vitamin D recommendations among US infants. Pediatrics. 2010; 125: 627-632. Ref.: https://goo.gl/yya7fL

12. Pepper KJ, Judd SE, Nanes MS, Tangpricha V. Evaluation of vitamin D repletion regimens to correct vitamin D status in adults. EndocrPract. 2009; 15: 95-103.Ref.: https://goo.gl/5L88r9

13. Binkley N, Gemar D, Engelke J, Gangnon R, Ramamurthy R, et al. Evaluation of Ergocalciferol or Cholecalciferol Dosing, 1,600 IU Daily or 50,000 IU Monthly in Older Adults. J Clin Endocrinol Metab. 2011; 96: 981-988. Ref.: https://goo.gl/2yrjvb

14. Niramitmahapanya S, Kaoiean S, Sangtawesin V, Patpanaprapan A, Bordeerat KN. Maternal Vitamin D3 Supplementation during Lactation Ameliorate Vitamin D Status of Breast-Fed Infants: Randomized Controlled Trial. Proceeding of the 97th Annual Meeting and Expo of Endocrine Society San Diego. 2015; 5-8. Ref.: https://goo.gl/6XmUuS

15. Holick MF, Binkley NC, Bischoff-Ferrari HA, Gordon CM, Hanley DA et al. Endocrine Society. Evaluation, treatment, and prevention of vitamin D deficiency: an Endocrine Society clinical practice guideline. J ClinEndocrinol Metab. 2011; 96: 1911-1930. Ref.: https://goo.gl/9tccYh

16. Jan Mohamed HJ, Rowan A, Fong B, Loy SL. Maternal serum and breast milk vitamin D levels: findings from the Universiti Sains Malaysia Pregnancy Cohort Study. PLoS One. 2014; 9: 100705. Ref.: https://goo.gl/Exj6BS

17. Charatcharoenwitthaya N, Nanthakomon T, Somprasit C, Chanthasenanont A, Chailurkit LO, et al Maternal vitamin $D$ status, its associated factors and the course of pregnancy in Thai women. Clin Endocrinol (Oxf). 2013; 78:126-133.Ref.: https://goo.gl/8azsyV

18. Ala-Houhala M, Koskinen T, Terho A, Koivula T, Visakorpi J. Maternal compared with infant vitamin D supplementation. Arch Dis Child. 1986; 61:1159-1163. Ref.: https://goo.gl/5T3QdH

19. Catherine AR, Christine LT, Ann LY, Heather BDV. Dietary reference intakes for calcium and vitamin D. Washington, DC: The National Academies Press. 2011. Ref.: https://goo.gl/cDFbSv

20. Birckbeck JA, Scott HF. 25-hydroxycholecalciferol serum levels in breast-fed infants. Arch Dis Child. 1980; 55: 691-695. Ref.: https://goo.gl/7vtyL8

21. Lamberg-Allardt C, Salmenper L, Perheentupa J, Siimes MA. Maternal vitamin D supplementation during lactation-effect on infant and mother. In: Norman AW, Schaefer K, Grigoleit H-G, von Herrath D, eds. Vitamin D. Chemical, biochemical and clinical update. Berlin: Walter de Gruyter; 1985: 664665 .

22. Rothberg AD, Pettifor JM, Cohen DR, Sonnendecker EWW, Ross FP. Maternal-infant vitamin D relationships during breastfeeding. J Pediatr. 1982; 101: 500-503. Ref.: https://goo.gl/QvYYHT

23. Hillman L, Sateesha S, Haussler M, Wiest W, Slatopolsky E, et al. Control of mineral homeostasis during lactation: interrelationships of 25-hydroxyvitamin D, 24,25-dihydroxyvitamin D, 1,25-dihydroxyvitamin D, parathyroid hormone, calcitonin, prolactin and estradiol. Am J Obstet Gynecol. 1981; 139: 471476. Ref.: https://goo.gl/NCvEvf 
Effect on Vitamin D status of Breastfeeding Infants after Vitamin D3 Supplementation during Breastfeeding Lactation: A double-blind randomiz controlled trial

\begin{tabular}{|c|c|c|c|}
\hline \multicolumn{4}{|l|}{\begin{tabular}{|l|} 
Supplement Data \\
Table General characteristics
\end{tabular}} \\
\hline Factors & Vit. D group $(n=35)$ & Placebo group $(n=33)$ & p-value \\
\hline Age(yrs) & $26.14 \pm 5.04$ & $28.24 \pm 5.08$ & 0.09 \\
\hline Body weight (kg.) & $57.03 \pm 11.27$ & $52.64 \pm 12.74$ & 0.16 \\
\hline Pre-gestational BMI $\left(\mathrm{kg} / \mathrm{m}^{2}\right)$ & $22.84 \pm 4.79$ & $21.63 \pm 5.42$ & 0.36 \\
\hline Pre-vitamin D status(nmol/L) & $53.82 \pm 14.17$ & $58.52 \pm 13.40$ & 0.17 \\
\hline Breast milk vitamin $\mathrm{D}(\mathrm{nmol} / \mathrm{L})$ & $79.86 \pm 18.27$ & $86.33 \pm 21.28$ & 0.19 \\
\hline Vitamin $D$ binding protein $(\mu \mathrm{g} / \mathrm{ml})$ & $172.08 \pm 6.44$ & $179.55 \pm 7.26$ & 0.70 \\
\hline Urine calcium (mEq/L) & $6.19 \pm 6.82$ & $6.09 \pm 8.54$ & 0.96 \\
\hline Gestational age (wks) & $38.40 \pm 0.89$ & $38.85 \pm 1.03$ & 0.06 \\
\hline Male infants (\%) & $18(51)$ & $17(52)$ & 0.59 \\
\hline Maternal $25(\mathrm{OH}) \mathrm{D}$ level at deliver $(\mathrm{nmol} / \mathrm{l})$ & $54.09 \pm 19.66$ & $57.53 \pm 15.78$ & 0.44 \\
\hline Cord blood 25(OH)D level (nmol/l) & $23.85 \pm 12.55$ & $25.80 \pm 11.74$ & 0.51 \\
\hline Colostrum 25(OH)D level $(\mathrm{nmol} / \mathrm{l})+$ & $79.86 \pm 18.27$ & $86.33 \pm 21.28$ & 0.19 \\
\hline Normal labor (\%) & $23(66)$ & $20(61)$ & 0.56 \\
\hline
\end{tabular}

